\title{
Strategi Kodim 1703/Manokwari Dalam Penanganan Konflik Sosial di Provinsi Papua Barat
}

\author{
Uchaimid Biridlo'i Robby ${ }^{\mathbf{1}}$, Dedi Akhiruddin ${ }^{2}$, \\ ${ }^{12}$ Program Studi Administarsi Publik, FIA, Universitas Krisnadwipayana, Jakarta
}

\begin{abstract}
The level of pluralism of the Indonesian nation, which has a variety of religions, cultures, languages and ethnicities, makes the Unitary State of the Republic of Indonesia a heterogeneous country, so it is common for friction to occur and cause social conflict by directing the masses to act irrationally. Conflict situations tend to be easily exploited by those who try to take advantage of them. Conflict parties have different understandings about the problems at hand. From this explanation explicitly, the importance of the involvement of Kodim 1703 / Manokwari of West Papua Province in dealing with social conflicts cannot only be borne by the handling of conflicts that have occurred but is an initial form of a persuasive approach to all elements of society. needed. This study aims to identify and analyze the strategy of Kodim 1703 / Manokwari of West Papua Province in handling social conflicts based on Law of the Republic of Indonesia Number 7 of 2012 in handling social conflicts in Indonesia, especially West Papua Province. The method used by the writer is descriptive qualitative method. The data obtained came from interviews with informants who were directly involved in the field during the handling of social conflicts in Manokwari. Based on the research results, it can be concluded as follows: (1) The role of Kodim 1703 / Manokwari in handling social conflicts in Manokwari City is limited by Law Number 7 of 2012 concerning Social Conflict Handling so that it is not optimal by involving all levels of society so that no one feels left out or ignored.
\end{abstract}

Keywords: Management Strategic and Social Conflict

\section{Pendahuluan}

Bangsa Indonesia yang memiliki beragam agama, budaya, bahasa, dan suku yang menjadikan Negara Kesatuan Republik Indonesia merupakan negara yang heterogen didalamnya namun dengan adanya semboyan Bhinneka Tunggal Ika yang memiliki arti bahwa berbeda-beda namun tetap satu jua, mewujudkan ciri khas bangsa Indonesia yang dikenal dunia dengan sikap dan senyum ramah tamahnya. Tingkat kemajemukan yang cukup tinggi tersebut merupakan suatu faktor yang sangat berpengaruh dan dapat digali serta dikembangkan hal-hal yang sangat positif diantaranya yang sangat mendominasi adalah dari segi pesona wisata budayanya yang dapat dijadikan sebagai sarana daya tarik bagi turis asing maupun pengunjung lokal untuk dapat menikmatinya.

Konflik merupakan kenyataan hidup, tidak terhindarkan dan sering bersifat kreatif. Konflik terjadi ketika tujuan masyarakat tidak sejalan, berbagai perbedaan pendapat dan konflik biasanya bisa diselesaikan tanpa kekerasan dan sering menghasilkan situasi yang lebih baik bagi sebagian besar atau semua pihak yang terlibat. Dalam setiap kelompok sosial selalu ada benih-benih 
pertentangan antara individu dan individu, kelompok dan kelompok, individu atau kelompok dengan pemerintah. Pertentangan ini biasanya berbentuk non fisik. Tetapi dapat berkembang menjadi benturan fisik, kekerasan dan tidak berbentuk kekerasan.

Sejak tahun 2013 Kabupaten Manokwari mengalami pemekaran menjadi tiga kabupaten yaitu Kabupaten Manokwari, Kabupaten Manokwari Selatan dan Manokwari Pegunungan Arfak. Selain terjadi pemekaran, terdapat empat distrik yang bergabung dengan Kabupaten Tambrauw. Oleh karenanya di tahun 2013 jumlah distrik yang semula 29 buah berkurang menjadi sembilan (9) distrik. Kabupaten Manokwari memiliki luas wilayah 4.650,32 kilometer persegi dengan wilayah terluas Distrik Masni seluas 1.406,10 kilometer persegi dan wilayah terkecil Distrik Manokwari Timur dengan luas 154,84 kilometer persegi.

Selain aspek ekonomis, separatisme di Papua di picu juga oleh konflik yang berakar dari kekecewaan historis, peminggiran sosial budaya, nasionalisme Papua dan diskriminasi politik dan hukum. Dalam perspektif kekecewaan historis, Ferry Kareth mempersoalkan keabsahan Pepera. Ia berpendapat bahwa Pepera itu tidak sah, sebab dilaksanakan di bawah tekanan. Pepera yang dilaksanakan tahun $1969 \mathrm{itu}$, dilaksanakan dengan perwakilan, bukan one man one vote sesuai New York Agreement. Sejarah mencatat bahwa masuknya Papua ke NKRI karena direbut, bukan atas dasar keinginan rakyat sendiri. Separatisme di Papua dimotori oleh Organisasi Papua Merdeka (OPM) yang disusul pembentukan Presidium
Dewan Papua (PDP). Gerakan ini telah ada sejak 1965 dengan melakukan aktivitas secara sporadis dalam gerakan militer yang melibatkan masyarakat. Perlawanan yang dilakukan OPM ditandai dengan penyanderaan, demonstrasi massa, pengibaran bendera, penempelan pamflet, aksi pengrusakan dan pelanggaran lintas batas negara. Beberapa dampak tersebut sangat rentan dapat menyebabkan rusaknya tatanan dan kenyamanan kehidupan masyarakat bahkan sampai terganggunya aspek keamanan.

Pencegahan konflik dilakukan antara lain melalui upaya memelihara kondisi damai dalam masyarakat, mengembangkan penyelesaian perselisihan secara damai, meredam potensi konflik, dan membangun sistem peringatan dini. Penanganan konflik pada saat terjadi konflik dilakukan melalui upaya penghentian kekerasan fisik, penetapan status keadaan konflik, tindakan darurat penyelamatan dan pelindungan korban, dan/atau pengerahan dan penggunaan kekuatan TNI berdasarkan Undang-Undang Republik Indonesia Nomor 7 Tahun 2012 tentang Penanganan Konflik Sosial. Berdasarkan isi dari undangundang tersebut harapannya TNI Angkatan Darat yang dalam hal ini diwakili oleh Komando Distrik Militer (Kodim) 1703/Manokwari, di Provinsi Papua Barat memiliki terlibatan aktif dalam penanganan konflik sosial mulai dari tahap pencegahan konflik, penghentian konflik sampai dengan pemulihan pasca konflik. Hal tersebut juga disebutkan bahwa salah satu tugas pokok TNI Angkatan Darat pada misi Operasi Militer Selain Perang (OMSP) diantaranya yaitu membantu tugas pemerintah daerah dan membantu 
Kepolisian Negara Republik Indonesia dalam rangka tugas keamanan dan ketertiban masyarakat sebagaimana yang diatur dalam Undang-Undang Republik Indonesia Nomor 34 Tahun 2004 tentang Tentara Nasional Indonesia.

Namun kenyataan yang terjadi masih adanya masalah pada mekanisme perlibatan Kodim 1703/Manokwari, Provinsi Papua Barat dalam menghadapi konflik sosial hanya dilibatkan pada saat penanganan konflik atau saat konflik telah terjadi, hal ini tentunya sangat menyulitkan posisi Kodim 1703/Manokwari, Provinsi Papua Barat karena penanganan konflik artinya konflik telah pecah dan berarti ada kerugian dari berbagai aspek akibat konflik tersebut. Karena untuk menghentikan kekerasan dalam suatu konflik sosial bukanlah hal yang mudah namun diperlukan adanya upaya awal berupa pendekatan kepada tokoh-tokoh antara pihak yang berkonflik, baik tokoh adat, tokoh agama dan tokoh masyarakat. Upaya ini dirasakan bukan hal yang mudah dimana kondisi masyarakat Indonesia yang majemuk.

\section{Metode Penelitian}

Penelitian ini menggunakan metode kualitatif untuk menganalisis startegi dan peran dalam penanganan konfilik sosial. Analisis yang dilakukan dengan menggunakan metode analisis deskriptif kualitatif yaitu pembahasan dan penjelasan keadaan serta permasalahan, selanjutnya mencoba untuk menganalisa secara logis, sistematis, dan konsisten dengan mengkaji secara rinci dan mendalam berkaitan dengan masalah tersebut.

\section{Hasil dan Pembahasan}

Soerjono Soekanto dalam (Ahmadi, 2009: 281), menyebutkan bahwa konflik merupakan suatu proses sosial individual atau kelompok yang berusaha untuk memenuhi tujuannya dengan jalan menentang pihak lawan yang disertai dengan ancaman dan/atau kekerasan. Lebih lanjut Coser dalam (Ahmadi, 2009: 281), berpendapat bahwa konflik adalah sebuah perjuangan mengenai nilai atau tuntutan atas status, kekuasaan dan sumber daya yang bersifat langkah dengan maksud menetralkan, mencederai atau melenyapkan lawan.

Gillin dan Gillin dalam (Ahmadi, 2009: 282), melihat konflik sebagai bagian dari proses interaksi sosial manusia yang saling berlawanan (oppositional process). Artinya, konflik adalah bagian dari proses interaksi sosial yang terjadi karena adanya perbedaan-perbedaan baik fisik emosi, kebudayaan dan perilaku. Kemudian Pruit dan Rubin dalam (Susan, 2009: 9), menyatakan bahwa konflik berarti persepsi mengenai perbedaan kepentingan (perceived divergence of interest) atau suatu kepercayaan bahwa aspirasi pihak-pihak yang berkonflik tidak dicapai secara simultan. Lebih lanjut dijelaskan bahwa jika memahami konflik pada dimensi ini, maka unsurunsur yang ada didalam konflik adalah persepsi, aspirasi dan aktor yang terlibat didalamnya. Oleh karena itu konflik sosial merupakan perbedaan pikiran, pandangan serta kepentingan seorang individu maupun kelompok dalam setiap tindakan sosial yang dilakukannya.

Thomas \& Kilmann, 1975 dalam (Olson, David., \& DeFrain, 2003) menjelaskan lima gaya manajemen konflik, yaitu: 
1) Kompetisi (competing). Gaya ini merupakan gaya yang berorientasi pada kekuasaan dimana seseorang akan menggunakan kekuasaan yang dimiliki untuk memenangkan konflik dengan biaya lawannya. Gaya ini memiliki tingkat keasertifan tinggi dan tingkat kerja sama rendah (Wirawan, 2010:140). Kompetisi menggunakan sikap yang bertentangan atau melawan pihak lain. Dalam gaya manajemen ini, pihak-pihak yang berkonflik terlibat dalam kompetisi dengan cara memaksa melalui kekuatan atau tindakan otoritas yang dimiliki oleh pihak yang berkonflik (Sudarmo, 2011:214).

2) Kolaborasi (collaborating). Kolaborasi merupakan gaya manajemen konflik yang berupaya menciptakan solusi yang sepenuhnya memuaskan pihak-pihak yang terlibat konflik. Kolaborasi bertujuan untuk mencari alternatif, dasar bersama dan berusaha untuk memenuhi harapan pihak-pihak yang berkonflik. Gaya manajemen ini memiliki tingkat keasertifan dan kerja sama yang sama (Wirawan, 2010: 140). Kolaborasi sering disebut problem solving karena pimpinan mencoba memuaskan keinginan setiap pihak sehingga tidak ada pihak yang merasa dirugikan (Sudarmo, 2011: 214215).

3) Kompromi (compromising). Gaya manajemen konflik tipe ini menggunakan strategi give and take, dimana kedua belah pihak yang berkonflik mencari alternatif tengah yang memuaskan sebagian keinginan mereka. Gaya ini merupakan gaya manajemen konflik tengah atau menengah. Gaya manajemen ini berada di tengah-tengah gaya kompetisi dan gaya kolaborasi (Wirawan, 2010: 141). Gaya manajemen ini berusaha menyelesaikan konflik dengan cara tawar-menawar terhadap solusi yang dapat diterima oleh semua pihak yang terlibat konflik. Masing-masing pihak yang terlibat konflik akan mendapatkan sedikit kemenangan dan sedikit kekalahan (Sudarmo, 2011: 214).

4) Menghindar (avoiding). Dalam gaya manajemen ini, kedua belah pihak yang sedang berkonflik berusaha menghindari konflik. Mereka menghindari konflik dengan cara menjauhkan diri dari pokok permasalahan, menunda pokok masalah hingga waktu yang tepat atau menarik diri dari konflik yang mengancam dan merugikan. Gaya tipe ini memiliki tingkat keasertifan dan kerja sama yang rendah (Wirawan, 2010: 141). Dalam gaya manajemen ini, pihak-pihak yang terlibat konflik beranggapan bahwa seakan-akan konflik tidak benar-benar ada. Gaya manajemen konflik menghindar menganggap bahwa ketidaksepakatan itu tidak ada, menarik diri dari situasi dan bersikap netral dalam berbagai hal (Sudarmo, 2011: 214).

5) Mengakomodasi (accomodating). Gaya manajemen konflik tipe ini mengabaikan kepentingan dirinya sendiri dan berupaya memuaskan kepentingan lawan konfliknya. Gaya manajemen konflik ini memiliki tingkat keasertifan rendah dan tingkat 
kerja sama tinggi (Wirawan, 2010: 142). Gaya manajemen ini berusaha menjaga harmoni dan mengabaikan perbedaanperbedaan yang terjadi di antara pihak-pihak yang berkonflik (Sudarmo, 2011: 214).

Resolusi Konflik dalam hal ini pihak ketiga dapat berupa lembaga pemerintah, lembaga arbitrase yang dibentuk berdasarkan undangundang, lembaga mediasi hingga pihak ketiga yang dibentuk berdasarkan kesepakatan pihakpihak yang terlibat konflik (Wirawan, 2010: 184). Intervensi pihak ketiga dapat dibagi menjadi lima, yaitu:

a) Resolusi konflik melalui proses pengadilan. Dalam resolusi melalui pengadilan perdata salah satu pihak atau kedua belah pihak yang terlibat konflik menyerahkan solusi konfliknya pada pengadilan perdata di Pengadilan Negeri melalui gugatan penggugat terhadap tergugat. Proses pengadilan umumnya didahului dengan permintaan hakim agar kedua belah pihak berdamai. Jika perdamaian tidak tercapai, hakim akan memeriksa kasusnya dan mengambil

keputusan.

Keputusan yang diambil hakim dapat berupa win-lose solution atau win-win solution. Apabila salah satu atau kedua belah pihak tidak puas atas keputusan hakim tersebut, mereka dapat mengajukan banding ke Pengadilan Tinggi. Jika keputusan di Pengadilan Tinggi masih belum memuaskan, mereka dapat mengajukan kasasi ke Mahkamah Agung. Di Mahkamah Agung, keputusan untuk peninjauan kembali dapat dimintakan apabila ada bukti baru (Wirawan, 2010: 184).

b) Resolusi konflik melalui proses atau pendekatan legislasi. Resolusi konflik melalui pendekatan legislatif adalah penyelesaian konflik melalui perundang-undangan yang dikeluarkan oleh lembaga legislatif. Konflik yang diselesaikan menggunakan metode ini adalah konflik yang besar dan meliputi populasi yang besar, tetapi mempunyai pengaruh terhadap individu anggota populasi. Dalam konflik politik seperti konflik mengenai batas daerah dan konflik pemekaran wilayah. Dalam bidang bisnis, misalnya konflik perlindungan konsumen serta konflik monopoli dan persaingan tidak sehat. Penyelesaian konflik melalui proses legislatif memerlukan banyak waktu karena memerlukan naskah akademik, penyusunan draft undang-undang dan pembahasan undang-undang di Dewan Perwakilan Rakyat (DPR). Setelah pembuatan undang-undang, peraturan pemerintah diperlukan untuk melaksanakannya (Wirawan, 2010: 185-186).

c) Resolusi konflik melalui proses administrasi. Resolusi konflik melalui proses administrasi adalah resolusi konflik melalui pihak ketiga yang dilakukan oleh lembaga negara bukan lembaga yudikatif yang menurut undangundang atau peraturan pemerintah diberi hak untuk menyelesaikan perselisihan atau konflik dalam bidang tertentu. Resolusi konflik ini banyak digunakan dalam bidang bisnis, ketenagakerjaan, lingkungan dan 
hak asasi manusia di Indonesia. Lembaga-lembaga negara yang diberi hak melakukan resolusi konflik melalui proses administrasi, seperti Komisi Pengawas Persaingan Usaha untuk menyelesaikan konflik terkait praktik monopoli dan persaingan usaha, Badan Penyelesaian Sengketa Konsumen yang bertugas menyelesaikan konflik antara pengusaha dan konsumen, Kementerian Tenaga Kerja dan Transmigrasi (Kemenakertrans) yang bertugas menyelesaikan masalah industrial. Selain itu juga terdapat Ombudsman yang merupakan pejabat publik non partisipan yang meneliti keluhan mengenai pelanggaran hak dan ketidakadilan yang dialami oleh anggota masyarakat oleh kebijakan dan perlakuan lembaga pemerintah, lembaga nirlaba dan perusahaan swasta (Wirawan, 2010: 186).

d) Resolusi perselisihan alternatif. Resolusi perselisihan alternatif (alternative dispute resolutionADR) adalah resolusi konflik melalui pihak ketiga yang bukan pengadilan dan proses administrasi yang diselenggarakan oleh lembaga yudikatif dan eksekutif. ADR terdiri atas mediasi dan arbitrase. Mediasi merupakan proses manajemen konflik dimana pihak-pihak yang terlibat konflik menyelesaikan konflik mereka melalui negosiasi untuk mencapai kesepakatan bersama (Wirawan, 2010: 200). Tujuan dari mediasi adalah untuk menciptakan win-win solution dan mencari kesepakatan bersama. Sedangkan arbitrase menurut Moore dalam (Wirawan, 2010: 214), adalah istilah umum proses penyelesaian konflik sukarela dimana pihak-pihak yang terlibat konflik meminta bantuan pihak ketiga yang imparsial (tidak memihak) dan netral untuk membuat keputusan mengenai obyek konflik. Keluaran dari keputusan arbitrase bisa bersifat nasehat dan tidak mengikat atau bisa juga berupa keputusan yang mengikat pihak-pihak yang terlibat konflik.

e) Rekonsiliasi. Rekonsiliasi adalah proses resolusi konflik yang mentransformasi ke keadaan sebelum terjadinya konflik, yaitu keadaan kehidupan yang harmonis dan damai (Wirawan, 2010: 195). Sedangkan menurut Undang-Undang Nomor 27 Tahun 2004 tentang Komisi Kebenaran dan Rekonsiliasi, rekonsiliasi adalah hasil dari suatu proses pengungkapan kebenaran, pengakuan dan pengampunan melalui Komisi Kebenaran dan Rekonsiliasi dalam rangka menyelesaikan pelanggaran hak asasi manusia yang berat untuk terciptanya perdamaian dan persatuan bangsa. Pihak-pihak yang terlibat konflik harus saling memaafkan dan tidak menyisihkan dendam yang dapat menimbulkan konflik baru di kemudian hari. Rekonsiliasi digunakan untuk menyelesaikan konflik politik dan sosial yang melanggar hak asasi manusia secara berat di Indonesia (Wirawan, 2010: 195).

Demokrasi dalam tatanan dunia yang makin terbuka mengakibatkan makin cepatnya dinamika sosial, termasuk faktor intervensi asing. 
Kondisi tersebut menempatkan Indonesia sebagai salah satu negara yang rawan konflik, terutama konflik yang bersifat horizontal. Konflik tersebut, terbukti telah mengakibatkan hilangnya rasa aman, timbulnya rasa takut masyarakat, kerusakan lingkungan, kerugian harta benda, korban jiwa dan trauma psikologis seperti dendam, benci, dan antipati, sehingga menghambat terwujudnya kesejahteraan umum. Sistem penanganan konflik di dalam peraturan perundang-undangan yang terkait dengan penanganan konflik masih bersifat parsial dan dalam bentuk peraturan perundangundangan yang dikeluarkan oleh pemerintah seperti dalam bentuk Instruksi Presiden, Keputusan Presiden dan Peraturan Presiden. Berbagai upaya penanganan konflik terus dilakukan berdasarkan peraturan perundang-undangan yang ada, termasuk membentuk kerangka regulasi baru. Dengan mengacu pada strategi penanganan konflik yang dikembangkan oleh Pemerintah, kerangka regulasi yang ada mencakup tiga strategi.

Pertama, kerangka regulasi dalam upaya pencegahan konflik seperti regulasi mengenai kebijakan dan strategi pembangunan yang sensitif terhadap konflik dan upaya pencegahan konflik. Kedua, kerangka regulasi bagi kegiatan penanganan konflik pada saat terjadi konflik yang meliputi upaya penghentian kekerasan dan pencegahan jatuhnya korban manusia ataupun harta benda. Ketiga, kerangka regulasi bagi penanganan pascakonflik, yaitu ketentuan yang berkaitan dengan tugas penyelesaian sengketa atauproses hukum serta kegiatan pemulihan, reintegrasi, dan rehabilitasi. Kerangka regulasi yang dimaksud adalah segala peraturan perundang-undangan, baik yang tertuang dalam Undang-Undang Dasar Negara Republik Indonesia Tahun 1945 maupun dalam peraturan perundang-undangan yang lain, termasuk di dalamnya Ketetapan Majelis Permusyawaratan Rakyat (TAP MPR).

Berdasarkan pemikiran tersebut, pada dasarnya terdapat tiga argumentasi pentingnya UndangUndang tentang Penanganan Konflik Sosial, yaitu argumentasi filosofis, argumentasi sosiologis, dan argumentasi yuridis. Pembentukan undang-undang tentang penanganan konflik sosial dilakukan melalui analisis sinkronisasi dan harmonisasi dengan peraturan perundangundangan yang terkait dengan penanganan konflik sosial. Adapun faktor-faktor yang melatarbelakangi terjadinya konflik etnis di antara di Manokwari, yakni: Pertama, faktor ketertiban masyarakat. Ketidakpatuhan masyarakat dalam rangka tanggungjawabnya dalam menjaga stabilitas keamanan dapat dilihat dari aksi-aksi merugikan yang menganggu ketertiban masyarakat umum itu sendiri. Kemunculan aksiaksi partikular yang meresahkan masyarakat umum menjadi bukti kurangnya kesadaran sebagian orang untuk berpartisipasi dalam menjaga ketertiban dalam interaksi antarmasyarakat. Hal ini semakin diperparah ketika aksi suatu oknum personal yang tidak bertanggungjawab namun pada perkembangan berikutnya sering di tarik menjadi sebuah permasalahan kelompok. Akhirnya yang terjadi ialah terjadi pembelokan fokus masalah, dari individu kepada kelompok. Kedua, faktor sosial budaya. Pada dasarnya, faktor akibat benturan 
sosial budaya antar kelompok dapat ditelusuri melalui analisis aktor seperti yang telah dikemukakan oleh Jeong. Aktor konflik merupakan seorang individu atau kelompok yang secara langsung ataupun tidak secara langsung turut mempengaruhi dinamika konflik. Dalam beberapa kali bentrokan yang bernuansa etnis di Kota Manokwari, maka dapat diklasifikasikan beberapa aktor-aktor yang terlibat. Pihak yang terlibat seringkali berasal dari suku-suku yang memiliki kepentingan dalam menuntut pihak lain yang dianggap merugikan mereka. Dalam kasus di Kota Manokwari bahwa pada umumnya hanya beberapa kelompok suku tertentu yang kerap kali melakukan aksi penyerangan dengan bermotif konflik etnis. Suku-suku tersebut apabila diamati memiliki beberapa persamaan yang kurang lebih menjadi faktor pendorong bagi mereka untuk melakukan konfrontasi. Ketiga, bagi sebagian orang, keadaan di Kota Manokwari selama ini terkesan tidak adil karena penguasaan sektor-sektor ekonomi lebih didominasi oleh para Pendatang daripada orang asli Papua. Persaingan di bidang informal selayaknya dikatakan sebagai persaingan yang tidak seimbang mengingat pengetahuan tentang ekonomi pasar dan manajemen perekonomian pasar masih terbatas terutama bagi orang-orang asli Papua. Hal ini berbanding terbalik dengan masyarakat pendatang, khususnya yang berasal dari Sulawesi Selatan yang telah lama menekuni usaha di sektor informal sehingga secara garis besar telah mengetahui cara menjalankan usaha yang menguntungkan.

Tuntutan untuk menaikan taraf ekonomi masyarakat asli Papua selama ini memang selalu digaungkan. Kondisi rata-rata masyarakat asli Papua yang masih di hidup dalam garis kemiskinan menjadi faktor pendorong isu ini terus diangkat. Salah satu penyebab faktor ekonomi masyarakat asli Papua masih ketinggalan dibandingkan dengan rata-rata masyarakat pendatang ialah karena pilihan profesi kerja masyarakat asli Papua lebih dominan pada sektorsektor formal seperti menjadi pegawai di pemerintahan dibandingkan dengan menjadi pelaku usaha di sektor-sektor informal. Yang terjadi ialah sektor informal lebih didominasi oleh masyarakat pendatang. Kempat, isu ideologi juga muncul sebagai konsekuensi lahirnya organisasi - organisasi prokemerdekaan Papua baik muncul dengan gerakan kekerasan seperti: Organisasi Papua Merdeka (OPM) maupun gerakan moderat nonkekerasan seperti Presidium Dewan Papua. Namun selain di bidang politik, perjuangan kemerdekaan Papua nampaknya ditempuh dengan jalan adat seperti yang dijalankan oleh Dewwan Adat Papua (DAP) yang merupakan lembaga yang dibentuk untuk menghimpun berbagai pimpinan suku/adat dan mengutamakan perjuangannya pada masalah-masalah hak-hak ulayat dan kebudayaan Papua.

Berkaitan dengan tugas pokok Kodim 1703/Manokwari dalam kaitannya dengan Undang-Undang Nomor 7 Tahun 2012 tentang Penanganan Konflik Sosial dapat dijelaskan startegi yang perlu dilakukan Kodim 1703/Manokwari dalam penanganan konflik sebagai berikut:

Pertama: mengadakan kegiatan pembinaan dan pembekalan secara 
tersebar di Makodim tiap-tiap wilayah tentang langkah dan cara menganalisa wilayah kepada prajurit Satkowil agar meningkatkan kepekaan tentang situasi wilayah; Kedua: memaksimalkan fungsi Forkopimda untuk berdiskusi mengenai potensi konflik di wilayah; Ketiga: dengan mengadakan kegiatan coffee morning untuk memberikan pengertian kepada media tentang pentingnya peran media dalam membantu memberikan informasi yang valid dalam rangka mencegah dan mengatasi ancaman konflik sosial; Keempat: mengadakan dialog dengan instansi terkait, tokoh pemuda, tokoh adat, tokoh agama dan tokoh masyarakat dengan cara face to face dialog sebagai upaya pencegahan potensi konflik yang ada di wilayahnya; Kelima: memberikan penekanan dan pengarahan kepada anggota terkait ancaman yang timbul sebagai dampak (Risk Explanation) dari konflik sosial dihadapkan; Keenam: meningkatkan fungsi kontrol dengan harapan dapat menekan tingkat keapatisan anggota terhadap pelaksanaan tugas di lapangan. Untuk mempermudah pemahaman dapat dilihat pada gambar berikut :

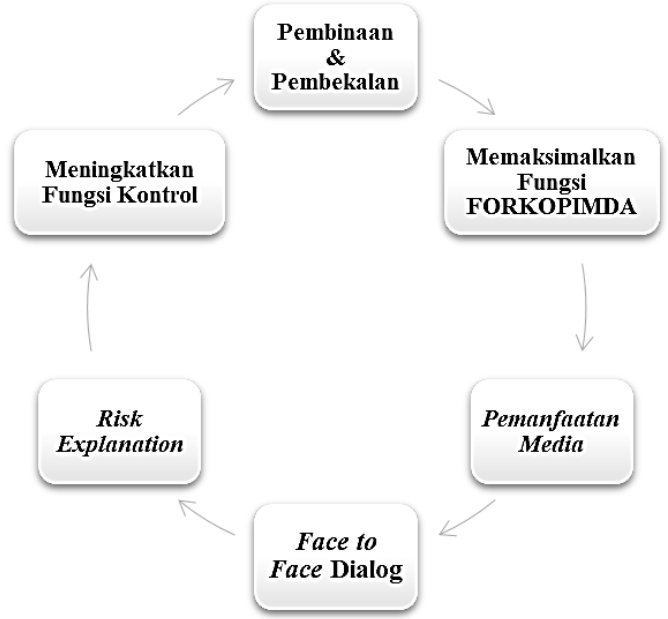

Gambar : Model Penanganan Konflik Sosial Kodim 1703/Manokwari

\section{Kesimpulan}

Strategi pemerintah dalam mengantisipasi konflik yang terjadi dengan mengerahkan kekuatan dari POLRI dan TNI masih belum cukup. Maka perlu adanya perencanaan yang matang mulai dari pencegahan konflik, persiapan jika terjadi konflik, perencanaan tanggap darurat saat terjadi konflik, dan rencana pemulihan pasca konflik. Pencegahan konflik dapat dilakukan oleh institusi intelijen melalui penyelidikan dan analisis situasi yang menghasilkan sistem deteksi dini dan peringatan dini untuk disajikan kepada pemerintah terutama aparat keamanan. Karena konflik biasanya tidak datang tiba-tiba dan banyak konflik yang terjadi karena "by design". Intelijen menjadi garda terdepan dalam fase pencegahan konflik ini dalam menyajikan informasi yang akurat kepada pemerintah atau aparat keamanan dalam hal ini TNI. Inti dari tahap pencegahan adalah pemerintah mempunyai sistem deteksi dini dan peringatan dini terhadap ancaman konflik dan segera melakukan tindakan supaya konflik tersebut tidak terjadi. Persiapan jika terjadi konflik harus dilakukan oleh pemerintah dan aparat keamanan. Skenario penanganan konflik seperti pengendalian huru hara, evakuasi dan kegiatan lain dapat dilatih dan disimulasikan. Ada atau tidak ada potensi konflik, aparat keamanan harus menyiapkan skenario penanganan konflik. Jika konflik benar-benar terjadi maka dalam situasi konflik atau darurat pemerintah harus tetap dapat mengendalikan situasi. Skenario situasi darurat harus disiapkan untuk mengantisipasi adanya pihak-pihak 
yang sengaja menginginkan situasi darurat terjadi guna menguntungkan tujuannya sendiri. Tahap terakhir adalah pemerintah mempunyai perencanaan untuk fase pemulihan jika terjadi konflik. Konflik massa sering kali menimbulkan korban jiwa dan kerugian harta benda. Jika hal ini terjadi maka akan muncul kekecewaan, sakit hati, dan kebencian bagi pihak yang menjadi korban dan mengalami kerugian. Skenario pemulihan korban dan keluarganya termasuk orang yang mengalami kerugian harus disiapkan untuk mencegah konflik lanjutan sebagai balas dendam. Fase pemulihan ini tidak hanya menjadi tanggung jawab pemerintah dan aparat keamanan, tetapi juga menjadi tanggung jawab masyarakat. Pemulihan konflik juga harus melibatkan segenap lapisan masyarakat sehingga tidak ada yang merasa ditinggalkan atau diabaikan.

\section{Referensi}

Ahmadi, A. (2009). Psikologi Sosial. Rineka Cipta.

Basrowi dan Suwandi. 2008. Memahami Penelitian Kualitatif. Rineka Cipta: Jakarta.

Fisher, Simon, dkk. 2001. Mengelola Konflik: Ketrampilan \& Strategi Untuk Bertindak. The British Council. Jakarta.

Moleong, Lexy J. 2006. Metode Penelitian Kualitatif. Remaja Rosdakarya: Bandung.

Olson, David., \& DeFrain, J. (2003). Marriages and Families: Intimacy, Diversity and Strengths. Mc Graw Hill.

Pruitt, Dean G. dan Jeffrey Z. Rubin. 2009. Teori Konflik Sosial. Pustaka Pelajar: Yogyakarta.
Robbins, Stephen P. dan Timothy A. Judge. 2008. Perilaku Organisasi Edisi (12 ed). Salemba Empat: Jakarta.

Sudarmo. (2011). Menuju Model Resolusi Konflik Berbasis

Governance (Memuat

Pengalaman Penelitian Lapangan tentang Isu Pedagang Kaki Lima dan Konflik Antar Kelompok). Percetakan UNS.

Sugiyono. 2009. Metode Penelitian Kuantitatif, Kualitatif, dan R\&D. Alfabeta: Bandung.

Susan, N. (2009). Sosiologi Konflik dan Isu-isu Konflik Kontemporer. Kencana Prenada Media Group.

Wirawan. (2010). Konflik dan Manajemen Konflik. Teori, Aplikasi, dan Penelitian. Salemba Humanika.

Wahyudi. 2011. Manajemen konflik Dalam Organisasi. CV Alfabeta: Bandung.

\section{Peraturan Perundang-Undangan}

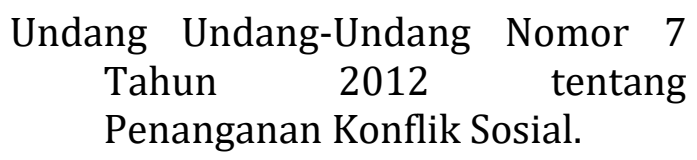

